\title{
Plant Growth, Fruit Yield and Quality, and Tolerance to Verticillium Wilt of Grafted Watermelon and Tomato in Field Production in the Pacific Northwest
}

\author{
Sacha Buller \\ Department of Horticulture, Washington State University, WSU Mount \\ Vernon Northwestern Washington Research \& Extension Center, 16650 \\ State Route 536, Mount Vernon, WA 98273-4768 \\ Debra Inglis \\ Department of Plant Pathology, Washington State University, WSU Mount \\ Vernon Northwestern Washington Research \& Extension Center, 16650 \\ State Route 536, Mount Vernon, WA 98273
}

\begin{abstract}
Carol Miles ${ }^{1}$
Department of Horticulture, Washington State University, WSU Mount Vernon Northwestern Washington Research \& Extension Center, 16650 State Route 536, Mount Vernon, WA 98273-4768
\end{abstract}

Additional index words. Citrullus lanatus, Solanum lycopersicum, bottle gourd, 'Strong Tosa', heirloom tomato

Abstract. Growth, fruit yield and quality, and potential tolerance to verticillium wilt (Verticillium dahliae) were compared among non-grafted, self-grafted, and grafted triploid watermelon (Citrullus lanatus Thunb., 'Crisp'n Sweet') and heirloom tomato (Solanum lycopersicum, 'Cherokee Purple'). Rootstocks for watermelon were 'Emphasis' bottle gourd (Lagenaria sicerarea) and 'Strong Tosa' interspecific squash hybrid (Cucurbita maxima $\times$ Cucurbita moschata), and rootstocks for tomato were 'Beaufort' and 'Maxifort' interspecific tomato (Solanum lycopersicum $\times$ Solanum habrochaites). Field trials were carried out in 2010 and 2011 at Hermiston and Eltopia (eastern Oregon and Washington, respectively) and Mount Vernon (western Washington). Grafted watermelon had significantly larger stem diameter than non-grafted and self-grafted plants both years at Mount Vernon, whereas there were no differences at Hermiston or Eltopia. Grafted tomato in $\mathbf{2 0 1 1}$ had significantly larger stem diameter than non-grafted and self-grafted plants at Eltopia and Mount Vernon, and 'Beaufort'-grafted plants were significantly taller than other treatments at Mount Vernon. Grafting did not impact watermelon or tomato fruit yield or quality at any location either year. Foliar symptoms of verticillium were not observed on 'Crisp'n Sweet' watermelon at the eastern locations either year; however, at Mount Vernon, 'Emphasis' and 'Strong Tosa'-grafted plants had significantly lower verticillium wilt severity than non-grafted and self-grafted plants both years. Microsclerotia were observed in all recovered watermelon stems sampled at Eltopia and Mount Vernon. $V$. dahliae was isolated from non-grafted and 'Emphasis'grafted 'Crisp'n Sweet' stems at Eltopia and non-grafted, self-grafted, and 'Strong Tosa'-grafted stems at Mount Vernon. Foliar symptoms of verticillium wilt and microsclerotia in stems were not observed on 'Cherokee Purple' plants at either location both years despite site histories of the disease. Grafting with 'Emphasis' and 'Strong Tosa' rootstocks may be an effective strategy for managing verticillium wilt on watermelon in western Washington; however, grafting 'Cherokee Purple' onto 'Beaufort' and 'Maxifort' did not provide any advantages for tomato under the field conditions of this study.

Worldwide, watermelon (Citrullus lanatus Thunb.) and tomato (Solanum lycopersicum) are grafted onto vigorous and disease-resistant rootstocks to ensure adequate yields where high salinity, soilborne pathogen populations, and/or unfavorable growing temperatures limit productivity (Dau et al., 2009; FernandezGarcia et al., 2002; Kubota et al., 2008; Oda, 2007; Sakata et al., 2007; Venema et al., 2008). Producer adoption of grafting in the
United States has been tentative, however, as a result of concerns about added labor costs, limited technical information regarding the grafting process, lack of information on regionally specific rootstock selection, and potential negative impact on fruit quality (Davis et al., 2008a, 2008b; Kubota et al., 2008; Rivard et al., 2010a; Sakata et al., 2007). Watermelon grafted onto interspecific squash rootstock $(C$. maxima $\times C$. moschata
Duchesne) were found to yield fruit that were significantly larger with firmer flesh than fruit from non-grafted plants (Huitron-Ramirez et al., 2009; Lee, 1994; Paroussi et al., 2007). Paroussi et al. (2007) found that 'Crimson Sweet' watermelon grafted onto interspecific squash hybrid rootstock (C. maxima $\times$ C. moschata Duchesne 'Mahmouth') had higher yields but lower total soluble solids (TSS) than when grafted onto bottle gourd rootstocks. Cushman and Huan (2008) found that TSS was unaffected by grafting. Bruton et al. (2009) evaluated fruit quality of nine watermelon cultivars grafted onto five rootstocks and found that when grafted onto C. maxima $\times C$. moschata and C. ficifolia rootstocks, watermelon fruit had higher firmness but equivalent lycopene content and TSS compared with non-grafted watermelon. For tomato, Flores et al. (2010) found that fruit from 'Kyndia', an indeterminate commercial cultivar, grafted onto 'UC82B', a determinate processing cultivar known to have high TSS, had higher TSS compared with fruit harvested from self-grafted tomato plants. Romano and Paratore (2001) found that grafting tomato with 'Beaufort' rootstock increased plant vigor and yield, but there was no effect on fruit quality.

Verticillium wilt is a soilborne disease caused by Verticillium dahliae Kleb. that impacts watermelon and tomato production throughout the world (Pegg and Brady, 2002) and is becoming an increasing problem in the Pacific Northwest (Washington, Oregon, and Idaho) (Maynard, 2001; Sunseri and Johnson, 2001). $V$. dahliae is a fungal pathogen that infects plant roots and rapidly colonizes xylem tissue, restricting water uptake and causing irreversible wilting and plant death (Pegg and Brady, 2002). V. dahliae produces microsclerotia within infected plant tissue and microsclerotia can persist in the soil for up to 14 years (Green, 1980; Menzies and Griebel, 1967; Pegg and Brady, 2002; Schnathorst, 1981).

There are few verticillium wilt-resistant watermelon cultivars available (Maynard, 2001; Pegg and Brady, 2002), and although there are no cucurbit rootstocks known to be resistant to verticillium wilt (Davis et al., 2008b), watermelon grafted onto many commercial cucurbit rootstocks have shown increased tolerance to verticillium wilt and delayed symptom onset of up to $20 \mathrm{~d}$ (Paplomatas et al., 2000; Paroussi et al., 2007). Rivard and Louws (2008) and Rivard et al. (2010b) found that grafting heirloom tomato onto vigorous rootstocks such as 'Beaufort' and 'Maxifort' effectively controlled bacterial wilt (caused by Ralstonia solanacearum), fusarium wilt (caused by Fusarium oxysporum f. sp. lycopersici), southern blight (caused by Sclerotium rolfsii), root-knot nematode (Meloidogyne spp.), and also increased plant vigor and yields. Although most commercial tomato cultivars have resistance to $V$. dahliae race 1 and some have resistance to race 2 (Bryan, 1925; Pegg and Brady, 2002), growers often choose susceptible cultivars such as heirlooms as a result of high customer demand, 
unique fruit color, shape and flavor, and higher market value (Grassbaugh et al., 1999; Rivard and Louws, 2008).

Vegetable grafting research has been conducted in warmer regions of the United States and focused on soilborne pathogens common to those climates. There is limited information on the performance of grafted watermelon and tomato plants in field production in northern temperate climates of the United States. The primary objective of this research was to evaluate plant growth, fruit yield and quality, and verticillium wilt severity of watermelon and tomato in field production at selected sites in the Pacific Northwest. The anticipated benefit of this research was to provide growers with regionally specific information on the potential of grafting to manage verticillium wilt.

\section{Materials and Methods}

Field trial locations and experimental designs. Field trials were conducted in two contrasting areas in the Pacific Northwest: the irrigated dryland Columbia Basin and the cool humid Puget Sound. In the Columbia Basin, watermelon plots were located within a commercial watermelon field at Hermiston, $\mathrm{OR}$, in 2010 and within a commercial melon field at Eltopia, WA, in 2011. Tomato plots were located within a commercial tomato field at the Eltopia site both years. In the coastal region, watermelon and tomato plots were located at the Washington State University Northwestern Washington Research and Extension Center (WSU NWREC) at Mount Vernon both years. Soil types are Adkins, Quincy, and Taunton fine sandy loam at Hermiston, classified as coarse-loamy, mixed, superactive, mesic Xeric Haplocalcids, Haplocambids, and Torripsamments; a Taunton very fine sandy loam at Eltopia, classified as coarse-loamy, mixed, superactive, mesic Xeric Haplodurids; and a Skagit silt loam at Mount Vernon, classified as a fine-silty, mixed, nonacid, mesic Typic Fluvaquent recently formed of alluvium and volcanic ash (Natural Resources Conservation Service, Soil Survey Staff, 2010). Both years, 20 soil samples per acre were taken with a soil probe at a depth of 6 inches in the spring before field planting to estimate populations of $V$. dahliae. Soil was bulked at

\footnotetext{
Received for publication 11 Mar. 2013. Accepted for publication 29 May 2013.

Funding for this project was provided by the Washington State Commission on Pesticide Registration, Washington State University Center for Sustaining Agriculture and Natural Resources, Organic Farming Research Foundation, Washington State University Department of Horticulture, Oregon State University, Northwest Agricultural Research Foundation, and the Pacific Northwest Vegetable Association.

The technical assistance of Jonathan Roozen, Babette Gundersen, Patti Kreider, and Jacky King is gratefully acknowledged.

${ }^{1}$ To whom reprint requests should be addressed; e-mailmilesc@wsu.edu.
}

each field site, and in 2010, Hermiston samples were assayed at the Oregon State University Hermiston Agricultural Research and Extension Center Plant Pathology Laboratory, and the Eltopia and Mount Vernon samples were assayed at the Oregon State University Plant Clinic in Corvallis, OR. In 2011, soil was sampled following the same sampling protocol and all samples were assayed at WSU Mount Vernon NWREC according to Butterfield and DeVay (1977).

For both crops, the field study design was a randomized complete block with four treatments. The treatments for watermelon were: 'Crisp'n Sweet' (triploid) non-grafted, self-grafted, and grafted onto 'Strong Tosa' interspecific squash hybrid (Cucurbita maxima $\times$ Cucurbita moschata) and grafted onto 'Emphasis' bottle gourd (Lagenaria sicerarea). There were five plants per plot at Hermiston and six plants per plot at Eltopia and Mount Vernon. There were four replicates at Hermiston and Mount Vernon and five replicates at Eltopia. However, shortly after transplanting at Eltopia, the study was reduced to two replicates as a result of plant mortality caused by severe winds. The treatments for tomato were: 'Cherokee Purple' (heirloom) non-grafted, self-grafted, and grafted onto 'Beaufort' (Solanum lycopersicum $\times$ Solanum habrochaites), and grafted onto 'Maxifort' (Solanum lycopersicum $\times$ Solanum habrochaites). There were six plants per plot and five replicates at both locations both years. Watermelon was grafted using the one-cotyledon splice technique (Miles et al., 2013), whereas tomato was grafted using the splice technique (Johnson et al., 2011). Self-grafting was included as a positive control treatment (Rivard and Louws, 2008).

Plot and field maintenance and plant establishment. All plants were propagated at WSU Mount Vernon NWREC and transported to the field locations. Both crops at all locations were planted on raised beds covered with black polyethylene mulch. Beds were spaced $1.4 \mathrm{~m}$ center-to-center, and plants were $0.6 \mathrm{~m}$ apart in a single row. Plants were drip-irrigated according to commercial practices and crop water use at each site (Hemphill, 2010), $\approx 134 \mathrm{~m}^{3} \cdot \mathrm{ha}^{-1}$ twice per week at Hermiston and Eltopia and 66 $\mathrm{m}^{3} \cdot \mathrm{ha}^{-1}$ twice per week at Mount Vernon. At Hermiston and Eltopia, watermelon and tomato studies were planted within commercial fields, which served as a buffer. A watermelon pollenizer cultivar, SP-4 at Hermiston and Crimson Sweet at Eltopia, was planted every six plants within the study plots. At Mount Vernon, one complete row of 'Crimson Sweet' watermelon was planted as outside rows on either side of the study and one plant was planted at the end of each row as a pollenizer and a buffer. For tomato at Mount Vernon, one complete row of tomato plants was planted on either side of the study and two plants were planted at the ends of each row as a buffer.

Plant growth. Stem diameter for both crops was measured just below the graft union and $\approx 2.5 \mathrm{~cm}$ above the soil line using a digital caliper (Model \# 700-126; Mitutoyo, Aurora, IL). Watermelon stem diameter was measured in 2010 at 41,55 , and $71 \mathrm{~d}$ after transplanting (DAT) at Hermiston and at 57, 65,72 , and 80 DAT at Mount Vernon. Plant growth was delayed at Mount Vernon as a result of cold early summer temperatures. In 2011 watermelon stem diameter was measured 42, 56, 71, and 85 DAT at Eltopia and 22, 38, 55, and 69 DAT at Mount Vernon.

There were insufficient watermelon plants for data collection in some treatments later in the season at Mount Vernon as a result of high disease pressure. Tomato stem diameter and plant height were only measured in 2011, at 42, 56, 71, and 85 DAT at Eltopia and 40, 53,66 , and 82 DAT at Mount Vernon. Plant height was measured from the soil line to the top of the plant crown. Area under growth progress curve (AUGPCs) values were calculated for stem diameter of both crops and for plant height of tomato at each location following Shaner and Finney (1977).

Harvest and yield. Watermelon fruit were harvested when the tendril and leaflet located at the leaf axil where the fruit stem arises had turned completely brown and dry (Georgia Vegetable Team, 2000) at 56, 71, and 87 DAT at Hermiston in 2010 and 95, 100, and 107 DAT at Eltopia in 2011. At Mount Vernon, no watermelon fruit reached marketable size either year as a result of the low growing degree-days, and so no yield data could be collected. Tomato fruit at both locations were harvested when $\approx 75 \%$ ripe. For both crops at each harvest date, the total number and weight of marketable fruit per plot were recorded, and for tomato, number and weight of unmarketable fruit also were recorded.

Fruit characteristics. Three representative marketable watermelon fruit were selected from each plot at each harvest date and average fruit diameter, length, and weight were measured. Each fruit was cut in half along the longitudinal axis, and a $5 \mathrm{~cm} \times 5 \mathrm{~cm} \times$ $5-\mathrm{cm}$ section of fruit tissue was taken from the center of one half of each fruit just below the latitudinal axis toward the blossom end. Fruit firmness was measured using a drillpress penetrometer (Ametek, Berwyn, PA) with a 4-mm cylindrical blunt-end tip that penetrated to the center of each section at a depth of $3.2 \mathrm{~mm}$. For tomato, five representative marketable fruit were selected from each plot at each harvest date and average fruit diameter, length, and weight were measured. A 1-cm thick laterally cut section was taken from the center of each fruit and firmness in the center of the pericarp of each section was tested as described previously.

Lycopene. Lycopene was quantified using a spectrophotometer method developed by Nagata and Yamashita (1992) and modified by Elena Lon Kan (personal communication, 2010). The sections of fruit tissue used for firmness measurements were frozen in $\mathrm{a}-10^{\circ} \mathrm{C}$ freezer and then homogenized in a blender such that there was one composite sample per plot per harvest date. Three 1-g subsamples 
were extracted with chilled $\left(4{ }^{\circ} \mathrm{C}\right)$ acetone: hexane (2:3) and lycopene was quantified in the supernatant by measuring the absorbance at $663,645,505$, and $453 \mathrm{~nm}$ using a Beckman DU-65 spectrophotometer (Beckman Coulter, Inc., Brea, CA).

Total soluble solids. TSS was measured as ${ }^{\circ}$ Brix using a Palm Abbe ${ }^{\mathrm{TM}}$ digital refractometer (MISCO, Cleveland, $\mathrm{OH}$ ). Watermelon juice was extracted directly from the fruit, whereas tomato juice was filtered through a wire mesh strainer into a glass beaker. Measurements were taken in a controlled laboratory environment with temperatures ranging between 21 and $22{ }^{\circ} \mathrm{C}$. The digital refractometer was equipped with automatic temperature compensation, and the digital refractometer was calibrated at the beginning of each day using deionized water.

Verticillium evaluation. Severity of verticillium wilt was rated visually for both crops during each growing season. Severity was determined as the total percentage of aboveground plant tissue per plot exhibiting typical symptoms consisting of $\mathrm{V}$-shaped leaf lesions, leaf chlorosis and necrosis, and plant wilting (Pegg and Brady, 2002; Schnathorst, 1981). Verticillium wilt symptoms were evaluated on watermelon at Hermiston at 41, 55, 71, and 87 DAT in 2010 and 42, 56, 71, 85, and 99 DAT at Eltopia in 2011. At Mount Vernon, disease severity was evaluated weekly beginning at $53 \mathrm{DAT}$ and ending at 101 DAT in 2010 and biweekly in 2011 beginning at 42 DAT and ending at 98 DAT. Verticillium wilt severity was evaluated on tomato at Eltopia at 41, 55, 71, and 87 DAT in 2010 and 42, 56, 71, 85, and 99 DAT in 2011. At Mount Vernon, disease severity was rated weekly in 2010 beginning at 21 DAT and ending at 103 DAT and biweekly in 2011 beginning at 35 DAT and ending at 109 DAT. Severity ratings were used to generate area under disease progress curve (AUDPC) values (Shaner and Finney, 1977). After the final rating each year, stems of one symptomatic watermelon and one random tomato plant (no symptoms were observed) from each plot at each field site were cut at the soil line to a $20-\mathrm{cm}$ length, surface-sterilized for $5 \mathrm{~min}$ in a $10 \%$ bleach solution, rinsed in tap water for $30 \mathrm{~s}$, cut longitudinally, and incubated in moisture chambers for 4 weeks at room temperature in the dark. Microsclerotia that formed in the stems were examined under a dissecting microscope (40x). In 2011, conidia from infected stems were swiped with small sterile filter paper strips and transferred onto $1 / 2$-potato dextrose agar medium. Isolates with growth characteristic of $V$. dahliae were sent to the Washington State University Puyallup Plant and Insect Diagnostic Laboratory for DNA sequencing (Applied Biosystems 3730xl; Applied Biosystems, Grand Island, NY) to confirm species identification.

Statistical analyses. Data were subjected to analysis of variance using PROC MIXED (SAS Version 9.2; SAS Institute, Cary, NC). When there was no significant interaction between grafting treatment and year, data were pooled at each location and analyzed using a split-plot model with grafting treatment as the main plot and year as the subplot. Non-pooled data were analyzed using a oneway model. Homogeneity of variance was assessed in all cases using Levene's test in SAS (Levene, 1960). Field locations and disease severity were analyzed separately as a result of possible differences in the pathogenicity and host specificity of $V$. dahliae at each location. Extremely low AUDPC values for rootstock-grafted treatments in field studies resulted in strongly heterogeneous variance; thus, ranked data were used for analysis. Treatment means were separated using LSMeans (SAS Institute, 2009).

\section{Results}

There was an average of $4.0 \mathrm{cfu} \cdot \mathrm{g}^{-1}$ soil of $V$. dahliae at Hermiston in 2010 and 3.0 cfu $\cdot \mathrm{g}^{-1}$ soil of $V$. dahliae at Eltopia in 2011. At Mount Vernon, an average of $18.0 \mathrm{cfu} \cdot \mathrm{g}^{-1}$ soil of $V$. dahliae was counted at the study location in 2010; in 2011, the study was repeated at the same field site and soil was not re-assayed.

Watermelon plant growth. Stem diameter at Hermiston in 2010 was measured incorrectly by a farm worker and data were discarded. Heavy winds after transplanting at Eltopia in 2011 reduced the number of plants per replicate below statistical validity. At Mount Vernon in 2010, stem diameter did not differ as a result of treatment at 57 DAT and was greatest for 'Strong Tosa'-grafted 'Crisp'n Sweet' watermelon on the other sample dates and comparable to 'Emphasis'-grafted watermelon at 65 and 72 DAT (Table 1). 'Strong Tosa' and 'Emphasis'-grafted 'Crisp'n Sweet' watermelon had the greatest mean AUGPC values for stem diameter. In 2011, 'Strong Tosa'-grafted 'Crisp'n Sweet' watermelon had the greatest stem diameter early in the season (22 DAT), equal to 'Emphasis'grafted plants midseason (38 and 55 DAT), and by the end of the season (69 DAT), there was no difference in stem diameter as a result of treatment. 'Emphasis' and 'Strong Tosa'grafted 'Crisp'n Sweet' plants had the greatest mean AUGPC values for stem diameter.

Watermelon yield. Marketable fruit yield and fruit size were unaffected by grafting at Hermiston in 2010 (data not shown). Additionally, fruit firmness, TSS, and lycopene content did not differ as a result of treatment. Yield data at Eltopia in 2011 and Mount Vernon both years were insufficient for statistical analysis; at Eltopia, there were too many missing plants per replicate (as a result of heavy winds), and at Mount Vernon, low growing degree-day accumulation during both summer seasons delayed fruit development such that none were mature by the end of the growing season.

Verticillium wilt on watermelon. Verticillium wilt symptoms were not observed at Hermiston in 2010 or Eltopia in 2011. At Mount Vernon, 'Emphasis' and 'Strong Tosa'-grafted 'Crisp'n Sweet' watermelon had significantly lower severity ratings for verticillium wilt than non-grafted and selfgrafted watermelon (Fig. 1). The severity rating for verticillium wilt reached $90 \%$ to $100 \%$ for non-grafted and self-grafted 'Crisp'n Sweet' watermelon in 2010 , and $40 \%$ to $50 \%$ in 2011, whereas the severity rating for rootstockgrafted 'Crisp'n Sweet' watermelon did not exceed $10 \%$ either year. Although verticillium wilt severity appeared to decline at the end of the season in 2011, the lowered rating was likely the result of severely affected plants dying and no longer being recorded. In 2010 and 2011, mean AUDPC values for wilt severity were significantly less for ' $\mathrm{Em}$ phasis' and 'Strong Tosa'-grafted 'Crisp'n Sweet' watermelon than for self- or nongrafted watermelon (Fig. 2).

Table 1. Mean stem diameter $(\mathrm{cm})$ and area under growth progress curve (AUGPC) values for stem diameter of 'Crisp'n Sweet' watermelon non-grafted, self-grafted, grafted on 'Emphasis' bottle gourd and grafted on 'Strong Tosa' interspecific squash hybrid in open-field production at Mount Vernon in 2010 and 2011

\begin{tabular}{|c|c|c|c|c|c|}
\hline \multirow[b]{2}{*}{ Treatment } & \multicolumn{4}{|c|}{ Days after transplanting } & \multirow[b]{3}{*}{ AUGPC } \\
\hline & 57 & 65 & 72 & 80 & \\
\hline 2010 & \multicolumn{4}{|c|}{ Stem diameter $(\mathrm{cm})$} & \\
\hline$\overline{\text { Non-grafted }}$ & 0.89 & $1.04 \mathrm{~b}^{\mathrm{z}}$ & $1.14 \mathrm{bc}$ & $1.19 \mathrm{c}$ & $24.56 \mathrm{~b}$ \\
\hline Self-grafted & 0.96 & $0.87 \mathrm{~b}$ & $1.00 \mathrm{c}$ & $0.97 \mathrm{~d}$ & $21.73 \mathrm{~b}$ \\
\hline Emphasis & 1.11 & $1.26 \mathrm{a}$ & $1.31 \mathrm{ab}$ & $1.42 \mathrm{~b}$ & $29.38 \mathrm{a}$ \\
\hline Strong Tosa & 1.25 & $1.38 \mathrm{a}$ & $1.41 \mathrm{a}$ & $1.58 \mathrm{a}$ & $32.22 \mathrm{a}$ \\
\hline$P$ value ${ }^{\mathrm{y}}$ & 0.48 & $<0.0001$ & 0.003 & $<0.0001$ & 0.0002 \\
\hline
\end{tabular}

\begin{tabular}{|c|c|c|c|c|c|}
\hline \multirow[b]{3}{*}{2011} & \multicolumn{4}{|c|}{ Days after transplanting } & \multirow[b]{3}{*}{ AUGPC } \\
\hline & 22 & 38 & 55 & 69 & \\
\hline & \multicolumn{4}{|c|}{ Stem diameter $(\mathrm{cm})$} & \\
\hline$\overline{\text { Non-grafted }}$ & $0.48 \mathrm{c}$ & $0.65 \mathrm{~b}$ & $0.96 \mathrm{~b}$ & 1.17 & $37.54 \mathrm{~b}$ \\
\hline Self-grafted & $0.49 \mathrm{c}$ & $0.65 \mathrm{~b}$ & $0.94 \mathrm{~b}$ & 1.10 & $36.67 \mathrm{~b}$ \\
\hline Emphasis & $0.61 \mathrm{~b}$ & $0.84 \mathrm{a}$ & $1.12 \mathrm{a}$ & 1.27 & $44.92 \mathrm{a}$ \\
\hline Strong Tosa & $0.66 \mathrm{a}$ & $0.88 \mathrm{a}$ & $1.10 \mathrm{a}$ & 1.26 & $45.63 \mathrm{a}$ \\
\hline$P$ value & 0.0001 & 0.002 & 0.03 & 0.12 & 0.007 \\
\hline
\end{tabular}

${ }^{z}$ Treatment differences were analyzed using the LSMeans statement to analyze differences in least square means. Treatments followed by the same letter in a column are not significantly different at $P \leq 0.05$. ${ }^{y}$ Significance of block and treatment effects analyzed using SAS (Version 9.2; SAS Institute, Cary, NC) with PROC GLM at $\alpha=0.05$. 
A

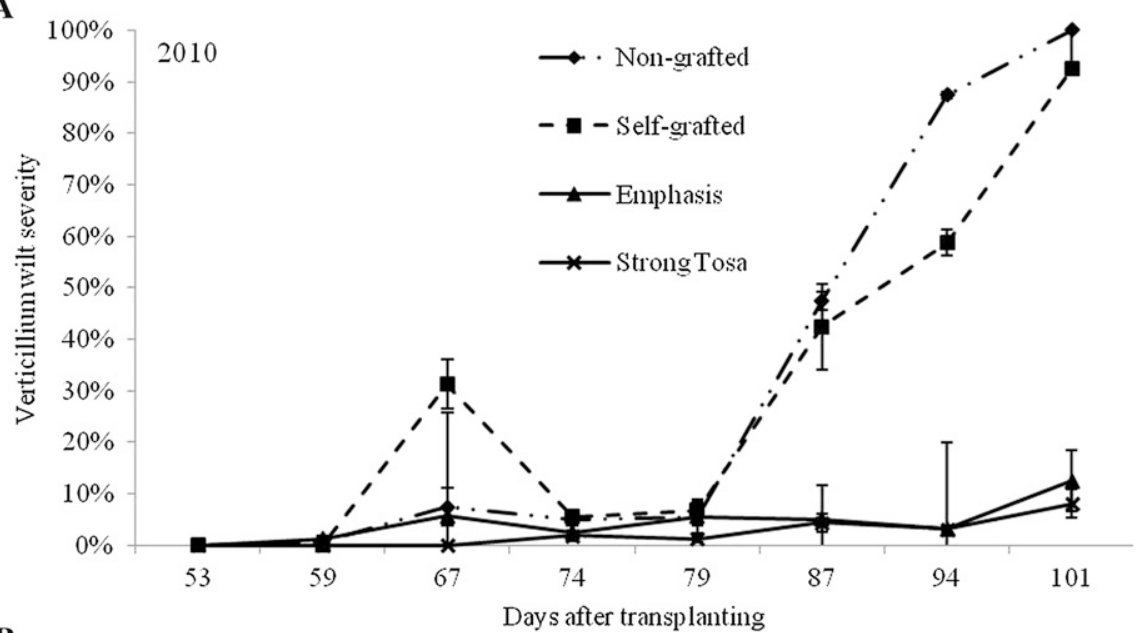

B

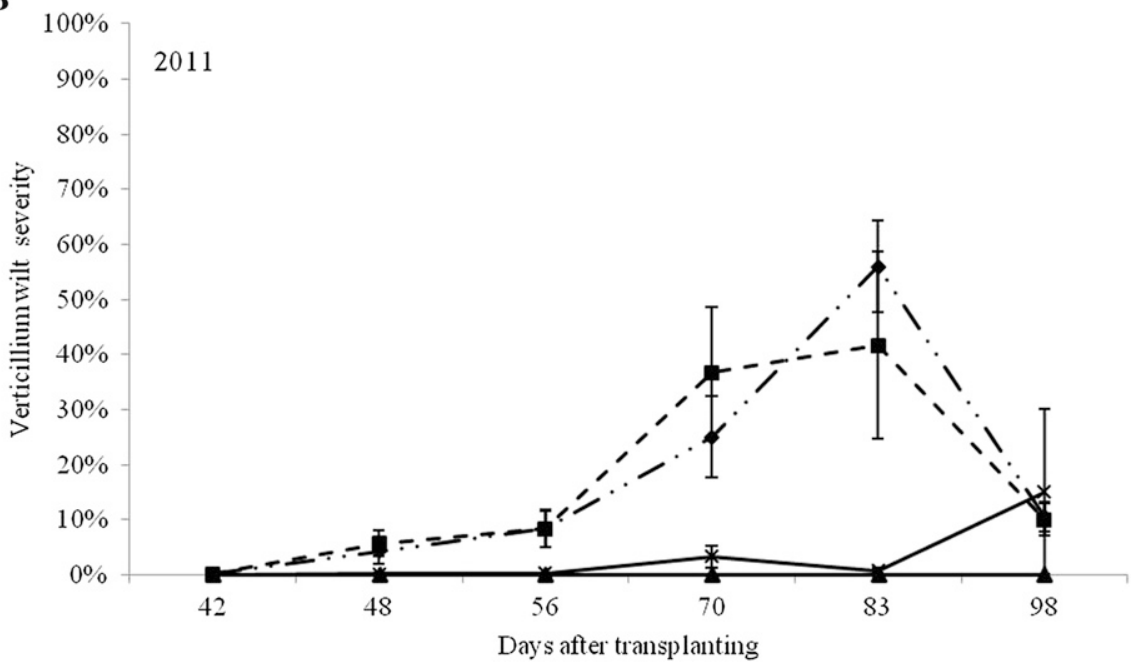

Fig. 1. Disease progress curves for severity of verticillium wilt of non-grafted and grafted 'Crisp'n Sweet' watermelon in field studies conducted at Mount Vernon in 2010 and 2011. Disease severity was rated as percent of aboveground plant tissue per plot exhibiting V-shaped leaf lesions, leaf chlorosis and necrosis, and plant wilting characteristic of verticillium wilt. 'Crisp'n Sweet' watermelon were selfgrafted and grafted onto 'Emphasis' bottle gourd and 'Strong Tosa' interspecific squash rootstocks with non-grafted 'Crisp'n Sweet' watermelon as the control. sE bars show significant differences in verticillium wilt severity among treatments (least square means, $P \leq 0.05$ ).

No microsclerotia were observed in any of the four sampled 'Crisp'n Sweet' watermelon stems per treatment from Hermiston in 2010. At Eltopia in 2011, microsclerotia were observed in all sampled 'Crisp'n Sweet' stems from non-grafted and self-grafted plants, three of six 'Emphasis'-grafted plants, and none of the four 'Strong Tosa'-grafted plants. $V$. dahliae was isolated from the infected non-grafted and 'Emphasis'-grafted 'Crisp'n Sweet' stems. At Mount Vernon in 2010, of the four 'Crisp'n Sweet' stems sampled per treatment, microsclerotia were present in a stem from three non-grafted plants, four self-grafted plants, three 'Emphasis'grafted plants, and two 'Strong Tosa'-grafted plants. In 2011 at Mount Vernon, four to six stems per treatment were sampled and microsclerotia were observed in the vascular tissue of a stem from four of six non-grafted plants, two of four self-grafted plants, none of the five 'Emphasis'-grafted plants, and four of five 'Strong Tosa'-grafted plants. Verticillium for stem diameter and was equivalent to 'Maxifort'-grafted tomato.

At Eltopia there was no significant difference in plant height among treatments at any sample date, and there was no significant difference among treatments in mean AUGPC value for plant height (Table 2). At Mount Vernon, 'Beaufort'-grafted 'Cherokee Purple' plants had the greatest plant height on all sample dates but plant heights were equivalent to 'Maxifort'-grafted plants on the first sample date. 'Beaufort'-grafted 'Cherokee Purple' plants also had a significantly greater mean AUGPC value for plant height compared with the other treatments.

Tomato yield. There were no differences in tomato yield among treatments at Eltopia in 2010 and 2011, and there was no interaction between grafting treatment and year for marketable or unmarketable yields (Table 3 ). Greater marketable fruit yield in 2011 than in 2010 was likely the result of more frequent harvesting in 2011. Fruit size and fruit quality at Eltopia were unaffected by grafting treatment either year, and there was no significant interaction between grafting treatment and year (Table 3). Fruit diameter, length, and weight were significantly smaller in 2010 than 2011. There was no significant difference in firmness and TSS between years, but lycopene content was significantly higher in 2010. Tomato plants at Mount Vernon were severely impacted by late blight (Phytophthora infestans) in 2010, and in 2011, the growing season was unseasonably cool; therefore, both years, there was insufficient yield for statistical evaluation.

Verticillium wilt on tomato. Symptoms of verticillium wilt were not observed on any plants of 'Cherokee Purple' at either location in either year. Additionally, no microsclerotia or verticillate conidia were observed in assayed 'Cherokee Purple' stems from either location either year.

\section{Discussion}

Although other studies have found significant increases in watermelon fruit firmness, fruit size, and yield as a result of grafting (Huitron-Ramirez et al., 2009; Lee, 1994; Paroussi et al., 2007), there were no differences in these parameters for 'Crisp'n Sweet' watermelon grafted onto 'Emphasis' and 'Strong Tosa' rootstocks in this study in the Pacific Northwest. TSS and lycopene content were also similar between grafted and nongrafted 'Crisp'n Sweet' watermelon, as has been reported by Bruton et al. (2009) and Cushman and Huan (2008). As a result of plant mortality and delayed maturity associated with unfavorable weather conditions, watermelon yield and fruit quality results in this study were limited to 1 year and one location. Although bottle gourd and squash rootstocks have been reported to increase cold tolerance of grafted watermelon plants (Lee, 1994), no such affect was observed in this study where the average soil temperature at Mount Vernon between 14 June and 15 Sept. in 2010 and 2011 was $18.2{ }^{\circ} \mathrm{C}$ and 
$17.5^{\circ} \mathrm{C}$, respectively (Washington State University, 2012).

Symptoms of verticillium wilt were not observed in 'Crisp'n Sweet' watermelon at Hermiston in 2010 or Eltopia in 2011 where $V$. dahliae soil inoculum levels were relatively low, $3.0 \mathrm{cfu} \cdot \mathrm{g}^{-1}$ soil. At Mount Vernon where $V$. dahliae soil inoculum levels were higher, $18.0 \mathrm{cfu} \cdot \mathrm{g}^{-1}$ soil, disease severity for non-grafted and self-grafted 'Crisp'n Sweet' reached $60 \%$ to $100 \%$. Microsclerotia were observed in stems of all treatments at Eltopia and Mount Vernon, except for 'Strong Tosa'grafted plants at Eltopia. These results suggest that 'Crisp'n Sweet' watermelon may not be affected by verticillium wilt when the soil population of $V$. dahliae averages less than $4.0 \mathrm{cfu} \cdot \mathrm{g}^{-1}$ soil at planting. Davis et al. (2008b) and Paplomatas et al. (2000) suggested that although cucurbit rootstocks have susceptibility to $V$. dahliae, plants grafted onto these rootstocks may exhibit delayed symptom expression.

For tomato, 'Cherokee Purple' grafted onto 'Beaufort' and 'Maxifort' rootstocks at both locations had increased stem diameter and plant height throughout the growing season and cumulatively as compared with non-grafted and self-grafted plants. However, there were no increases in yield, fruit

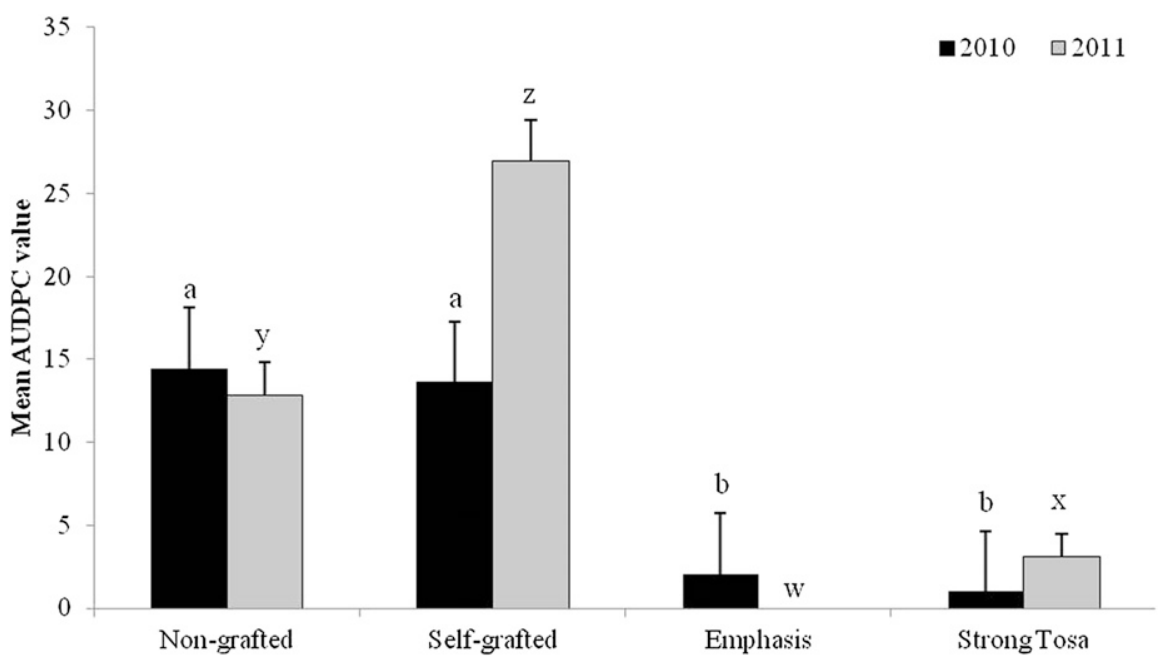

Fig. 2. Means for area under disease progress curve (AUDPC) values for verticillium wilt on grafted and non-grafted 'Crisp'n Sweet' watermelon at Mount Vernon in 2010 and 2011. Disease severity was rated as percent of aboveground plant tissue per plot exhibiting V-shaped leaf lesions, leaf chlorosis and necrosis, and plant wilting characteristic of verticillium wilt. 'Crisp' $n$ Sweet' watermelon was selfgrafted and grafted onto 'Emphasis' bottle gourd and 'Strong Tosa' interspecific squash rootstock. Non-grafted 'Crisp'n Sweet' plants were included as an experimental control. AUDPC values were calculated from at least four disease ratings during the growing season. Treatment differences were analyzed by comparing least square means using the LSMeans statement. Significant treatment differences are denoted in alphabetical order in 2010 and reverse alphabetical order in 2011. Treatments followed by the same letter were not significantly different at $P \leq 0.05$.

size, or fruit quality as a result of grafting in this study. Leonardi and Giuffrida (2006) similarly observed that 'Beaufort'-grafted tomato plants had significantly greater stem diameter and plant height relative to selfgrafted tomato plants. Although other studies have found increased TSS and lycopene content in fruit of grafted tomato plants (Flores et al., 2010), the results of our research showed no increase in either TSS or lycopene content

Verticillium wilt symptoms were not observed in non-grafted, self-grafted, or grafted 'Cherokee Purple' heirloom tomato at either location in either year. However, eggplant planted immediately adjacent to the tomato study at both locations in both years developed severe and obvious symptoms of verticillium wilt (Johnson et al., 2013). Although eggplant is reported to be very susceptible to $V$. dahliae (O'Brien, 1983), higher soil populations may be required to cause damage on tomato. Pegg and Brady (2002) stated that $V$. dahliae microsclerotial counts of $100 \mathrm{cfu} \cdot \mathrm{g}^{-1}$ of soil led to $100 \%$ tomato crop loss. Bhat and Subbarao (1999) compared the host specificity of $V$. dahliae isolates obtained from 14 different vegetables, including eggplant, and found that none of the isolates caused wilting or reduced plant height in tomato. The authors concluded that many isolates of Verticillium cause severe vascular discoloration and wilting only if they are aggressive to the host. Tsror et al. (2001) found that $V$. dahliae from vegetative compatibility group (VCG) $2 \mathrm{~A}$ isolated from eggplant caused a higher incidence of verticillium wilt in tomato than $V$. dahliae $\mathrm{VCG}$ 2B or the VCG 4B isolates from eggplant. The VCG of $V$. dahliae was not determined at either location in our study because the identification of VCG required expertise that was beyond the scope of this study. Under the cool environmental conditions of the Pacific Northwest, 'Beaufort' and 'Maxifort' provided no tomato yield or fruit quality advantages when grafted with 'Cherokee Purple.'

Table 2. Mean stem diameter $(\mathrm{cm})$, mean plant height, and area under growth progress curve (AUGPC) values for stem diameter and plant height of 'Cherokee Purple' heirloom tomato non-grafted, self-grafted, and grafted on 'Beaufort' and grafted on 'Maxifort' interspecific tomato hybrid rootstocks in open-field production at Eltopia and Mount Vernon in 2011.

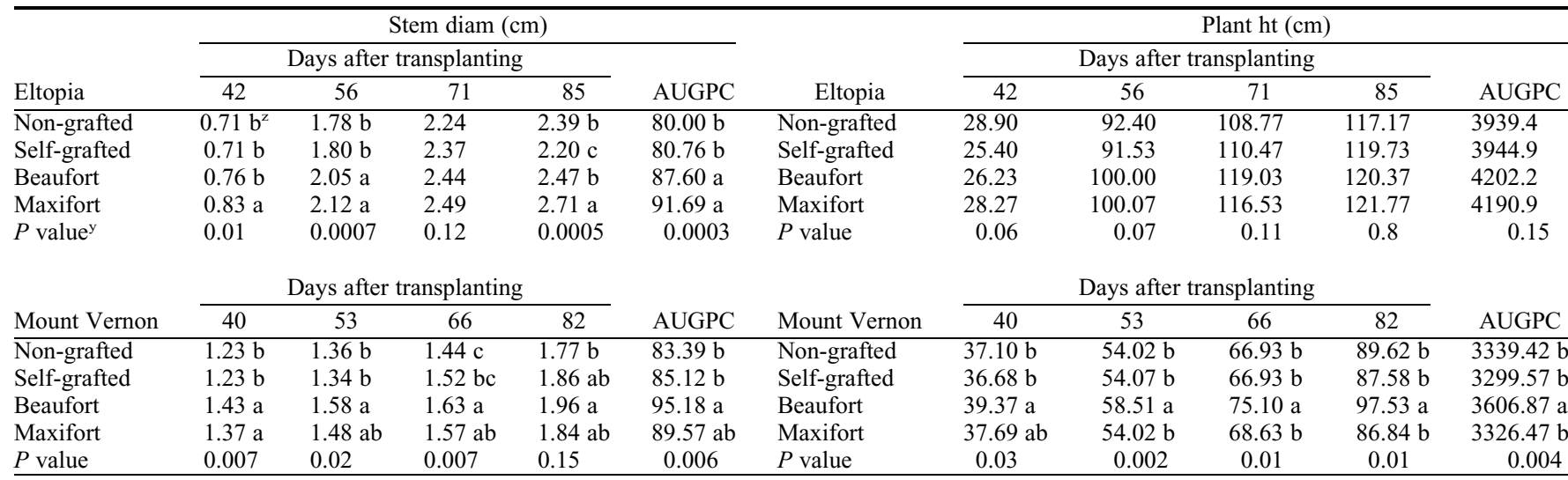

${ }^{2}$ Treatment differences were analyzed using the LSMeans statement to analyze differences in least square means. Treatments followed by the same letter in a column are not significantly different at $P \leq 0.05$.

${ }^{y}$ Significance of block and treatment effects analyzed using SAS (Version 9.2; SAS Institute, Cary, NC) with PROC GLM at $\alpha=0.05$. 
Table 3. Mean effects of grafting treatment and year on mean number and weight of marketable and unmarketable fruit and fruit diameter $(\mathrm{cm})$, length $(\mathrm{cm})$, weight (g) per marketable fruit, firmness (N), total soluble solids (TSS; ${ }^{\circ}$ Brix), and lycopene $\left(\mu \mathrm{g} \cdot \mathrm{g}^{-1}\right)$ for 'Cherokee Purple' heirloom tomato non-grafted, selfgrafted, grafted on 'Beaufort', and grafted on 'Maxifort' interspecific tomato rootstocks in field production at Eltopia in 2010 and 2011.

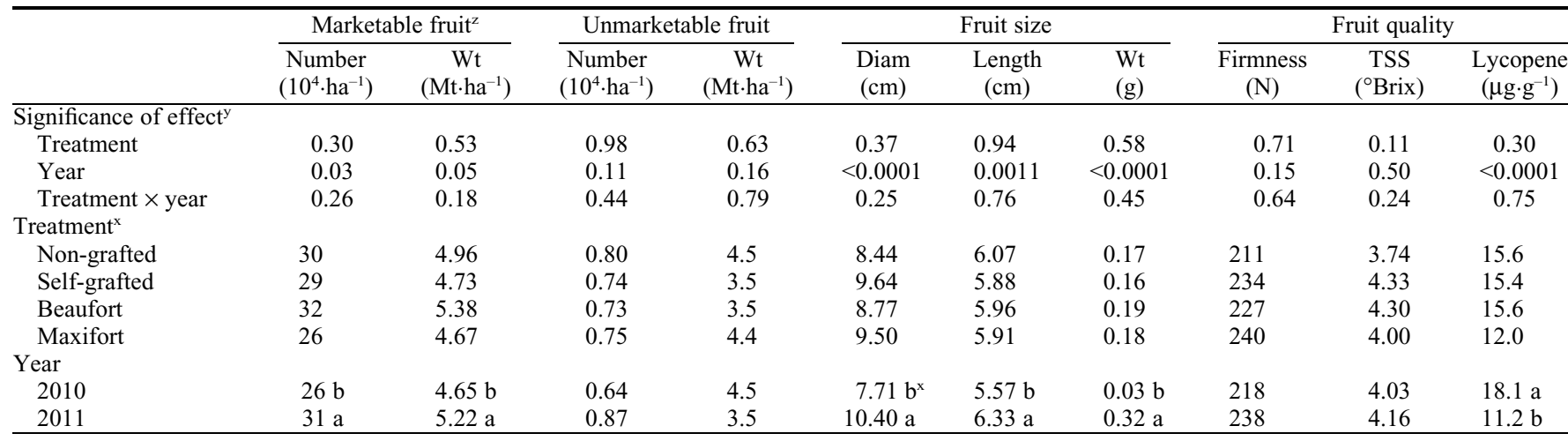

${ }^{\mathrm{z}}$ Number and weight of marketable and unmarketable fruit were calculated based on six plants in each plot; spacing was $1.4 \mathrm{~m}$ between and $0.6 \mathrm{~m}$ in the bed. ${ }^{\mathrm{y}}$ Significance of effects analyzed using SAS (Version 9.2; SAS Institute, Cary, NC) with PROC GLM at $\alpha=0.05$.

${ }^{\mathrm{x}}$ Treatment differences were analyzed using the LSMeans statement to analyze differences in least square means. Treatments followed by the same letter in the same row were not significantly different at $P \leq 0.05$.

\section{Conclusions}

In this study in the Pacific Northwest, there were no differences in fruit yield or quality for 'Crisp'n Sweet' watermelon grafted onto 'Emphasis' and 'Strong Tosa' rootstocks or for 'Cherokee Purple' tomato grafted onto 'Beaufort' and 'Maxifort' rootstocks. Although 'Crisp'n Sweet' watermelon grafted onto these two rootstocks had a higher rate of growth and increased tolerance to $V$. dahliae than nongrafted and self-grafted plants at Mount Vernon, these advantages did not translate into earlier fruit set or fruit maturity. 'Cherokee Purple' tomato may have resistance to $V$. dahliae or require high soil populations of the pathogen; thus, successful cultivation in Washington soils infested with $V$. dahliae may not require intensive verticillium wilt management strategies. Further studies are needed to determine if 'Beaufort' and 'Maxifort' rootstocks have resistance or tolerance to V. dahliae.

\section{Literature Cited}

Bhat, R.G. and K.V. Subbarao. 1999. Host range specificity in Verticillium dahliae. Phytopathology 89:1219-1225.

Bruton, B.D., W.W. Fish, W. Roberts, and T.W. Popham. 2009. The influence of rootstock selection on fruit quality attributes of watermelon. The Open Food Science J. 3:15-34.

Bryan, M.K. 1925. Phytopathological notes. Verticillium wilt of tomato. Phytopathology 15:187188.

Butterfield, E.J. and J.E. DeVay. 1977. Reassessment of soil assays for Verticillium dahliae. Phytopathology 67:1073-1078.

Cushman, K.E. and J. Huan. 2008. Performance of four triploid watermelon cultivars grafted onto five rootstock genotypes: Yield and fruit quality under commercial growing conditions. ISHS Proc IV, Seed, Transplant and Stand Establishment of Hort. Crops. Acta Hort. 782:335-342.

Dau, V.T., N.V. Dang, D.H. Nguyen, L.T. Phan, T.T.M. Le, H.T. Phan, and L.W. Burgess. 2009. A simplified technique for grafting watermelon onto resistant cucurbit rootstocks for control of fusarium wilt of watermelon in Nghe An Province, Vietnam. Australasian P1. Dis. Notes. 4:114-116.
Davis, A.R., P. Perkins-Veazie, R. Hassell, A. Levi, S.R. King, and X. Zhang. 2008a. Grafting effects on vegetable quality. HortScience 43 : 1670-1672.

Davis, A.R., P. Perkins-Veazie, Y. Sakata, S. Lopez-Galarza, J.V. Maroto, S.G. Lee, Y.C. Huh, Z. Sun, A. Miguel, S.R. King, R. Cohen, and J.M. Lee. 2008b. Cucurbit grafting. Crit. Rev. Plant Sci. 27:50-74.

Fernandez-Garcia, N., V. Martinez, A. Cerda, and M. Carvajal. 2002. Water and nutrient uptake of grafted tomato plants grown under saline conditions. J. Plant Physiol. 159:899-905.

Flores, F.B., P. Sanchez-Bel, M.T. Estan, M.M. Martinez-Rodriguez, E. Moyano, B. Morales, J.F. Campos, J.O. Garcia-Abellan, M.I. Egea, N. Fernandez-Garcia, F. Romojaro, and M.C. Bolarin. 2010. The effectiveness of grafting to improve tomato fruit quality. Sci. Hort. 125: 211-217.

Georgia Vegetable Team. 2000. Commercial watermelon production. University of Georgia Coop. Ext. Serv. Bul. 996.

Grassbaugh, E., T. Harker, B. Bergelund, and M Bennett. 1999. Specialty and heirloom tomato production and marketing. Dept. Health and Consumer Sci.: Agr. Res. and Dev. Ctr. Bul. 684.

Green, R.J., Jr. 1980. Soil factors affecting survival of microsclerotia of Verticillium dahliae. Phytopathology 70:353-355.

Hemphill, D. 2010. Watermelon. Vegetable Production Guides, Oregon State University Extension Service. 25 May 2013. <http://horticulture. oregonstate.edu/content/watermelon- $0>$.

Huitron-Ramirez, M.V., M. Ricardez-Salinas, and F. Camacho-Ferre. 2009. Influence of grafted watermelon plant density on yield and quality in soil infested with melon necrotic spot virus. HortScience 44:1838-1841.

Johnson, S., C. Miles, and D. Inglis. 2013. First report of Verticillium wilt caused by $V$. dahliae on grafted Solanum aethiopicum in Washington. Plant Dis. 97:840.

Johnson, S., C. Miles, P. Kreider, and J. Roozen. 2011. Vegetable grafting: Eggplants and tomato. Wash. St. Univ. Ext. Pub. FS052E.

Kubota, C., M. McClure, N. Kokalis-Burelle, M.G. Bausher, and E.N. Rosskopf. 2008. Vegetable grafting: History, use, and current technology status in North America. HortScience 43:1664 1669.

Lee, J.-M. 1994. Cultivation of grafted vegetables. I. Current status, grafting methods, and benefits. HortScience 29:235-239.
Leonardi, C. and F. Giuffrida. 2006. Variation of plant growth and macronutrient uptake in grafted tomatoes and eggplants on three different rootstocks. Europ. J. Hort. Sci. 71: 97-101.

Levene, H. 1960. Robust tests for equality of variances, p. 278-292. In: Olkin, I., S.G. Ghurye, W. Hoeffding, W.G. Madow, and H.B. Mann (eds.). Contributions to probability and statistics: Essays in honor of Harold Hotelling. Stanford Univ. Press, Palo Alto, CA.

Maynard, D.N. 2001. Watermelons characteristics, production, and marketing. ASHS, Alexandria, VA.

Menzies, J.D. and G.E. Griebel. 1967. Survival and saprophytic growth of Verticillium dahliae in uncropped soil. Phytopathology 57:703709.

Miles, C., L. Hesnault, S. Johnson, and P. Kreider. 2013. Vegetable grafting: Watermelon. Wash. St. Univ. Ext. Pub. FS100E.

Nagata, M. and I. Yamashita. 1992. Simple method for simultaneous determination of chlorophyll and carotenoids in tomato fruit. J. Jpn. Soc. Food Sci. and Tech. 39:925-928.

Natural Resources Conservation Service, Soil Survey Staff. 2013. United States Department of Agriculture. Web soil survey. 28 Jan. 2013. $<$ http://websoilsurvey.nrcs.usda.gov/>.

O'Brien, M.J. 1983. Evaluation of eggplant accessions and cultivars for resistance to Verticillium wilt. Plant Dis. 67:763-764.

Oda, M. 2007. Vegetable seedling grafting in Japan. Proc. XXVII on Global Hort.: Diversity and Harmony (ed. J. Janick). Acta Hort. 759: 175-180.

Paplomatas, E.J., K. Elena, and A. Tsagkarakou. 2000. Screening tomato and cucurbit rootstocks for resistance to Verticillium dahliae. EPPO Bul. 30:239-242.

Paroussi, G., F. Bletsos, G.A. Bardas, J.A. Kouvelos, and A. Klonari. 2007. Control of Fusarium and Verticillium wilt of watermelon by grafting and its effect on fruit yield and quality. Proc. III ${ }^{\text {rd }}$ Balkan Symp. on Veg. and Potatoes. Acta Hort. 729, ISHS.

Pegg, G.F. and B.L. Brady. 2002. Verticillium wilts. CABI Publishing, New York, NY.

Rivard, C. and F. Louws. 2008. Grafting to manage soilborne diseases in heirloom tomato production. HortScience 43:2104-2111.

Rivard, C., S. O'Connell, M. Peet, and F. Louws. 2010a. Grafting tomato with interspecific rootstock to manage diseases caused by Sclerotium 
rolfsii and southern root-knot nematode. Plant Dis. 94:1015-1021.

Rivard, C., O. Sydorovych, S. O'Connell, M.M. Peet, and F.J. Louws. 2010b. An economic analysis of two grafted tomato transplant production systems in the U.S. HortTechnology 20:794-803.

Romano, D. and A. Paratore. 2001. Effects of grafting on tomato and eggplant. Proc. 5th Protect. Cult. Mild Winter Clim. (Eds. Fernandez, Martinez, and Castilla). Acta Hort. 559:149-153.

Sakata, Y., T. Ohara, and M. Sugiyama. 2007. The history and present state of the grafting of cucurbitaceous vegetables in Japan. Proc III ${ }^{\text {rd }}$ IS on Cucurbits (Ed. R. McConcie and G. Rogers). Acta Hort. 731, ISHS.
SAS Institute. 2009. SAS 9.2 user's guide. 2nd Ed. 1 June 2013. <http://support.sas.com/ documentation/92/index.html $>$.

Schnathorst, W.C. 1981. Life cycle and epidemiology of Verticillium, p. 81-111. In: Mace, M.E., A.A. Bell, and C.H. Beckman (eds.). Fungal wilt diseases of plants. Academic Press, New York, NY.

Shaner, G. and R.F. Finney. 1977. The effect of nitrogen fertilization on the expression of slowmildewing resistance in Knox wheat. Phytopathology 67:1051-1056.

Sunseri, M. and D.A. Johnson. 2001. Verticillium wilt. Wash. State Univ. Coop. Ext. Bul. EB1908, Pullman, WA.
Tsror, L., M. Hazanovsky, S. Mordechi-Lebiush, and S. Sivan. 2001. Aggressiveness of Verticillium dahliae isolates from different vegetative compatibility groups to potato and tomato. Plant Pathol. 50:477-482.

Venema, J.H., E.D. Boukelien, J.M. Bax, P.R.v. Hasselt, and J.T.M. Elzenga. 2008. Grafting tomato (Solanum lycopersicum) onto the rootstock of a high-altitude accession of Solanum habrochaites improves suboptimal-temperature tolerance. Environ. Exp. Bot. 63:359-367.

Washington State University. 2012. The Washington agricultural weather network Version 2.0. Prosser, WA. 1 May 2012. <http://weather. wsu.edu/>. 